\title{
Siting Study of Solar Thermoelectric Plants in the State of Minas Gerais
}

\author{
Chigueru Tiba1, Ruibran Januário dos Reis Reis², Júlio César Ezequiel da Costa3, \\ Verônica Wilma Bezerra Azevedo1, Jõao Francisco Abreu², Melina Amoni Silveira Alves², \\ Daniel Pereira Guimarães ${ }^{4}$, Marco Aurélio Dumont Porto ${ }^{3}$ \\ ${ }^{1}$ Nuclear Energy Department, Federal University of Pernambuco, Recife, Brazil \\ ${ }^{2}$ Programa de Pós-Graduação em Geografia, PUC, Belo Horizonte, Brazil \\ ${ }^{3}$ Companhia Energética de Minas Gerais, Belo Horizonte, Brazil \\ ${ }^{4}$ Embrapa Milho e Sorgo, Sete Lagoas, Brazil \\ Email: tiba@ufpe.br
}

Received 21 July 2014; revised 18 August 2014; accepted 12 September 2014

Copyright (C) 2014 by authors and Scientific Research Publishing Inc.

This work is licensed under the Creative Commons Attribution International License (CC BY). http://creativecommons.org/licenses/by/4.0/

(c) (i) Open Access

\section{Abstract}

The generation of heliothermal electricity has received increasing attention throughout the world in countries such as Spain, the USA, Germany and many others. In Brazil, this type of energy generation in the form of large projects (above $80 \mathrm{MW}$ ) remains unexplored. However, it is known that in the country, there are extensive areas of normal direct irradiation with high intensity and a low seasonality factor, especially in the semiarid regions in Brazil, mainly the North and Northeast of Minas Gerais. Moreover, these Minas Gerais regions have other significant characteristics for the installation of these plants: proximity to transmission lines, flatness, the fact that the respective vegetation is not endangered, a suitable land use profile (availability of land not used in agriculture), low wind speed, low population density, and, most recently, an increase in the demand for local electric energy due to the economic growth above the Brazilian average rate. Furthermore, the introduction of solar plants in that region, due to its distributed nature, will bring development and growth to the region (normally poor) by generating employment and income. This article presents a study of the optimal location of thermoelectric plants in the semiarid regions of Minas Gerais, conducted with Geographical Information System (GIS) technology. GIS consists of a set of specialised resources that allow the manipulation of spatial data, bringing efficiency and agility in the identification of suitable places for the installation of solar plants, while simultaneously enabling the consideration of future scenarios for energy planning, with its respective impact, costs and benefits. The study has identified very promising solar irradiation levels for the electric generation by solar energy, whether thermoelectric or photovoltaic, reaching an annual solar irradiation of $2700 \mathrm{kWh} / \mathrm{m}^{2}$ in the summer and in the range of $2200-2400 \mathrm{kWh} / \mathrm{m}^{2}$ on an annual basis. This area includes a vast region in the North/Northeast of the state, which also has continuous and flat regions, with slopes inferior to $3 \%$; in addition, high-quality hydro resources 
are abundant and well distributed. Furthermore, the Minas Gerais region has few areas with high agriculture profile and reduced quantity of protected units. Therefore, generally speaking, the coverage of the transmission lines in that region is suitable. Considering the most relevant aspects mentioned before, and taking as a reference the micro-region limits defined by the IBGE, the following micro-regions were classified as the most promising ones: 1) Janaúba, 2) Januária, 3) Pirapora and Unaí, 4) Pirapora and Paracatu, 5) Curvelo and Três Marias, and 6) Patrocínio and Araxá. Finally, it is important to highlight that this potential might be explored gradually in the medium term, with the shortage of other supply sources, the scale up and readiness of such technologies, as well as the creation of a complex solar-wind-hydro system that leverages the strong complementarity of such resources, as has been observed.

\section{Keywords}

Solar Energy, Thermoelectric Solar Plant, Geographical Information System, Promising Regions in the Minas Gerais

\section{Introduction}

\subsection{Description of the Technologies}

A thermoelectric solar plant is mainly composed of the following components: a solar collector concentrator in which the collection and the concentration are performed through the reflection or diffraction of the light; the absorber, which absorbs light and transfers heat to a thermal fluid; a heat storage system; a steam generator system; and a conventional system of thermal energy conversion into electricity (Figure 1). Basically, in the following four concepts, the collector sections can be differentiated: Figure 1(a) and Figure 1(b) are linear and bidimensional concentrators, respectively, and Figure 1(c) and Figure 1(d) are tri-dimensional ones. Concentrators Figure 1(b) and Figure 1(d) have reflective components known as heliostats in which each mirror reflects the light for a linear or volumetric recipient, while concentrators Figure 1(a) and Figure 1(c) are image formers.

\subsection{Recent Evolution of the Technologies and Their Commercial Insertion}

The recent evolution of solar thermoelectric plants began in the 1980s and can be summarised in the following highlights [1]:

1980s

- 1981-The solar towers known as SOLAR I (10.0 MW, EUA), CESA I (1.2 MW Spain), THEMIS (2.5 MW, France), EURELIOS (1.0 MW, Italy) and NIO (1.0 MW, Japan) were connected to an electric network.

- 1984-Solar Electric Generating System I (SEGS), a thermoelectric solar plant with a parabolic cylinder concentrator with 13.8 MW power, starts operating. 1990s

- 1990-Nine SEGS-type plants were implanted in commercial bases (SEGS 1, 13.8 MWe; SEGS 2 to 7, 30 MWe and SEGS 8 and 9.80 MWe), totaling 354 MWe.

- 1991-The main developer of SEGS, Solar Light, declares bankruptcy.

- 1996-The solar tower, SOLAR II (Barstow, USA), a 10 MW plant, starts operation and exhibits storage viability with molten salts.

- 1990-2000 —Despite the interruption of the installation of large commercial systems, basic research continued. 2000s

- 2004 - A Parabolic Disc with a Stirling engine of $150 \mathrm{~kW}$ was implemented at Sandia Laboratory, the Spanish government implements a decree, stimulating the purchase of 200 MW of thermoelectric solar energy with a guaranteed fee.

- 2006-Installation of the P\&D (1 MW) plant of cylinder parabolic technology in Saguaro, USA.

- 2007-Implementation in Spain of the commercial plant tower type PS10 and Nevada I of 60 MW with cylinder parabolic technology. 


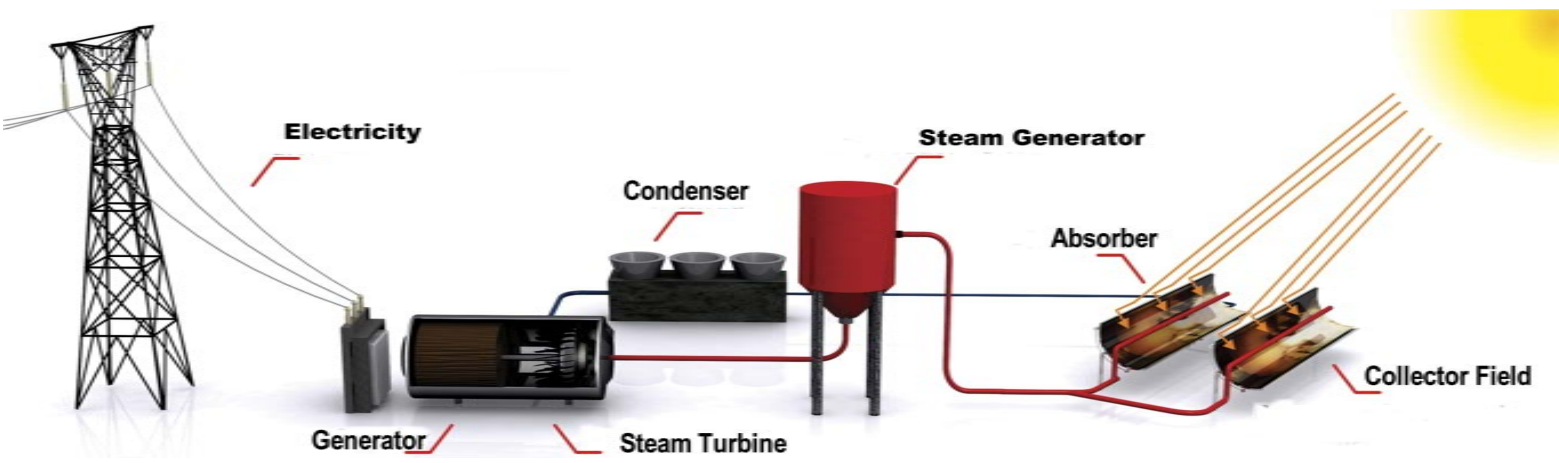

(a)

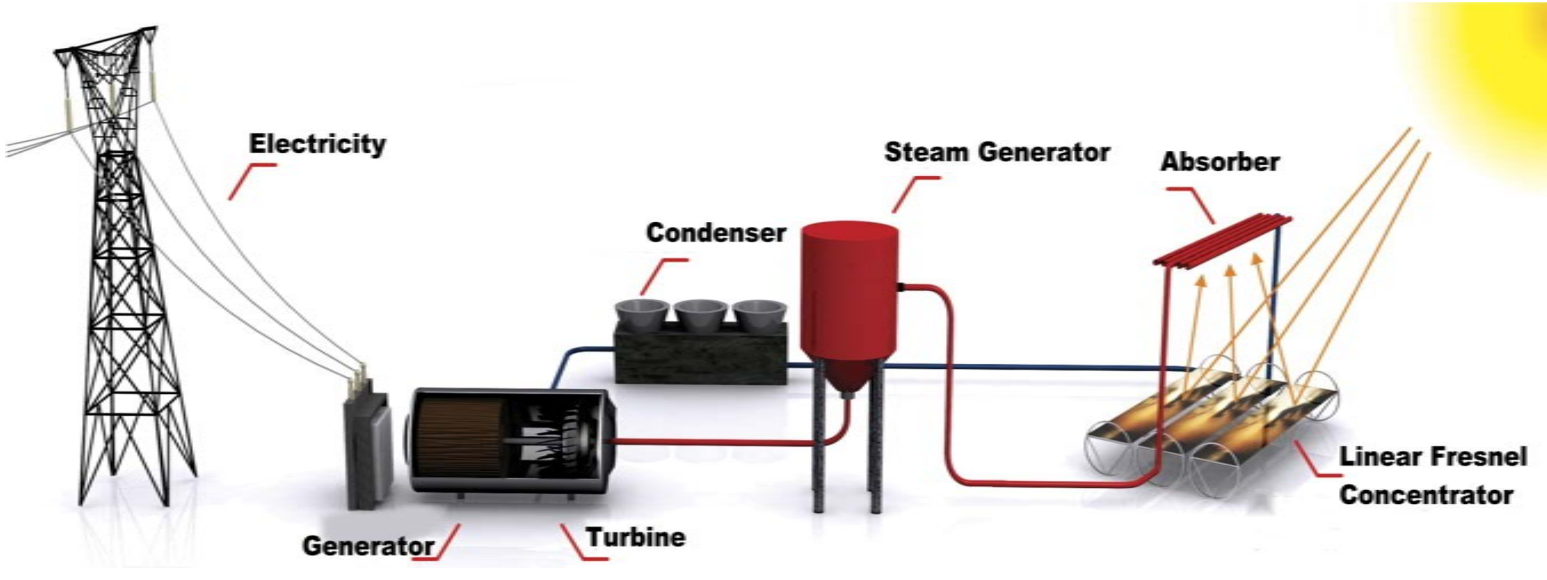

(b)
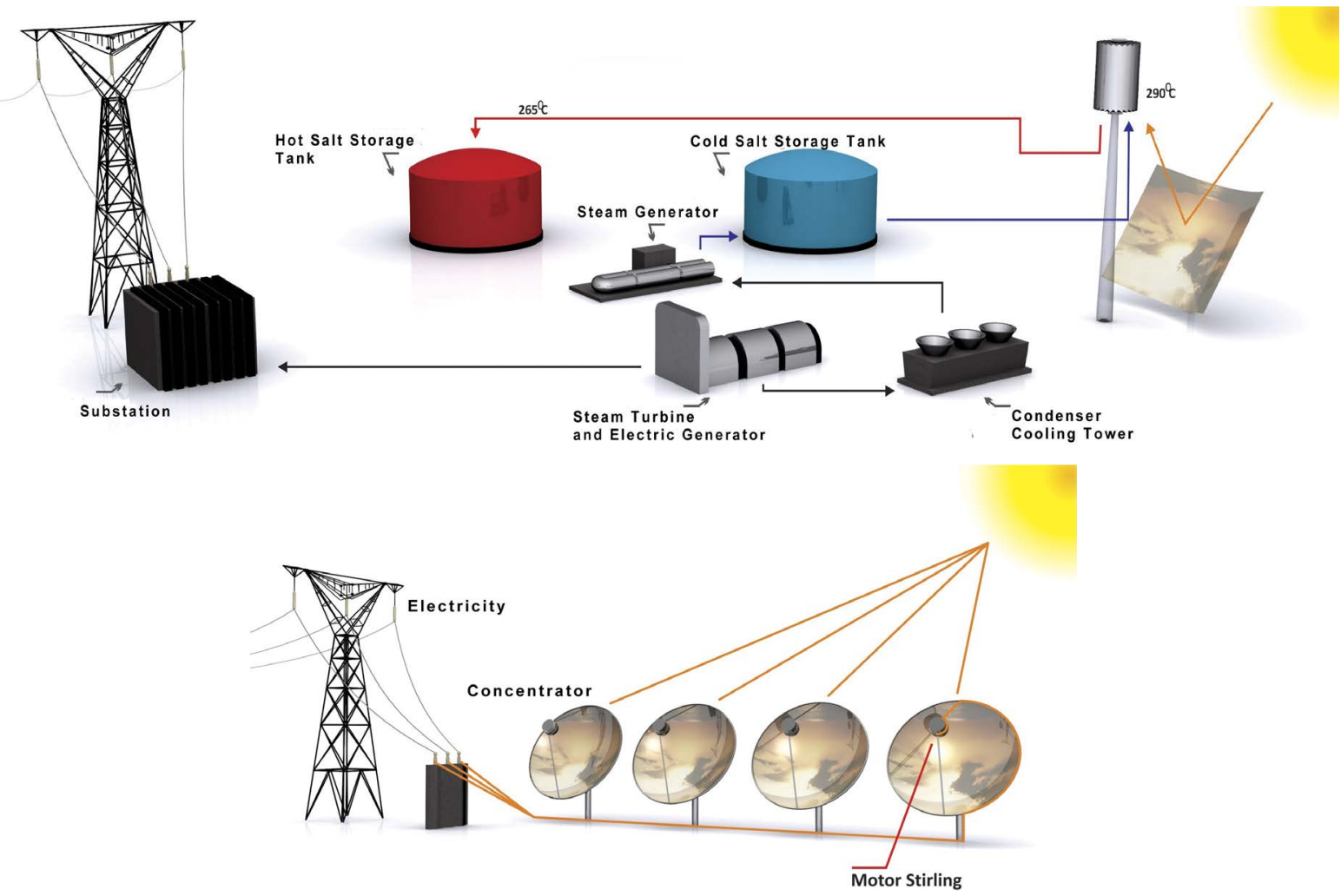

(c) 


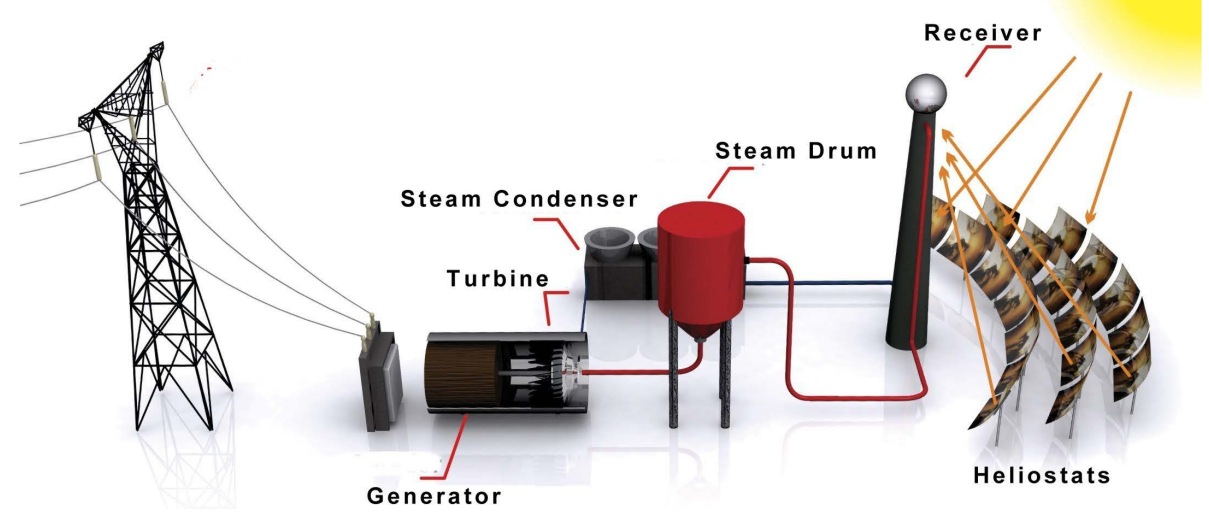

(d)

Figure 1. Solar concentration type for the generation of electric energy: (a) Cylinder Parabolic Concentrator; (b) Fresnel Linear Concentrator; (c) Parabolic Disc; and (d) Power Tower. Source: Atlas Solarimétrico de MG (2012).

\section{Start of the commercialization growth}

- 2008-Andasol I (Spain, 50 MW), the cylinder parabolic power plant, is commissioned; also, Kimberlina (EUA, $5 \mathrm{MW}$ ), the first thermoelectric solar plant with a Fresnel linear concentrator, was installed.

- 2009-In Spain: the PS20 (20 MW solar tower), cylindrical parabolic power plants in Puertollano, Andasol II and La Risca were built, each of 50 MW and Linear Fresnel technology PE1 of 1.4 MW. In the U.S., the Sierra Sun Tower (5 MW) was built.

- 2012 - The cumulative capacity of solar thermal power plants installed worldwide was $2236 \mathrm{MW}$, with the majority of the plants using cylindrical parabolic concentration technology (95\%).

The plants of the SEGS (Solar Electric Generation Systems) were installed at the end of the last century, representing the largest (354 MWe) and most successful example of installed solar thermal technology using cylindrical parabolic concentrators. The nine SEGS plants were built at three different places in the Mojave Desert in California (USA), between 1984 and 1991, and continue to be in commercial operation, demonstrating its technical and commercial reliability.

After a break in the installation of such systems for approximately 15 years, there was a vigorous resumption of this technology in the mid-2000s. In 2012, the cumulative amount of solar thermal power plants located worldwide was of $2236 \mathrm{MW}$, with the majority being of cylindrical parabolic concentration technology (95\%). Estimates of the thermal solar plants under construction or announced publicly are discrepant due to the use of different criteria, such as different period consideration and the absence of updating the changes in the project in terms of the power produced. According to [2], approximately 2590 MW were under construction and 4508 MW were announced in the U.S., 1080 MW in Spain, and 4386 MW in the rest of the world. Carefully considering these numbers, it is reasonable to say that the pace of growth, the rate of accumulation of experience, and the scale gains in the coming years will be spectacular. Therefore, based on the learning curve prepared by [3] (Figure 2), it is likely that in the next 10 years, the cost of solar thermal energy would be equal to the cost of energy from the conventional network.

\subsection{Thermoelectricity in the Context of Electricity Generation in MG}

The state of Minas Gerais has used almost all of the large water resources for hydroelectric power generation. Nevertheless, the options of energy imports, the use of other local renewable sources (PCH, wind and solar) or the creation of conventional thermal power plants (with fuel oil, gas, coal, or nuclear) remain undeveloped. The main barriers to importing energy or creating nuclear and conventional thermal power plants are as follows: 1) Amazon hydroelectricity import costs are much higher than the generation itself, besides the environmental problems that add uncertainty to the activity; 2) fossil fuels that have increasing prices; 3) environmental problems and "invisible" subsidies (externalities), which are increasingly questioned by society; and finally 4) in the case of nuclear energy, the risk of catastrophic accidents. 


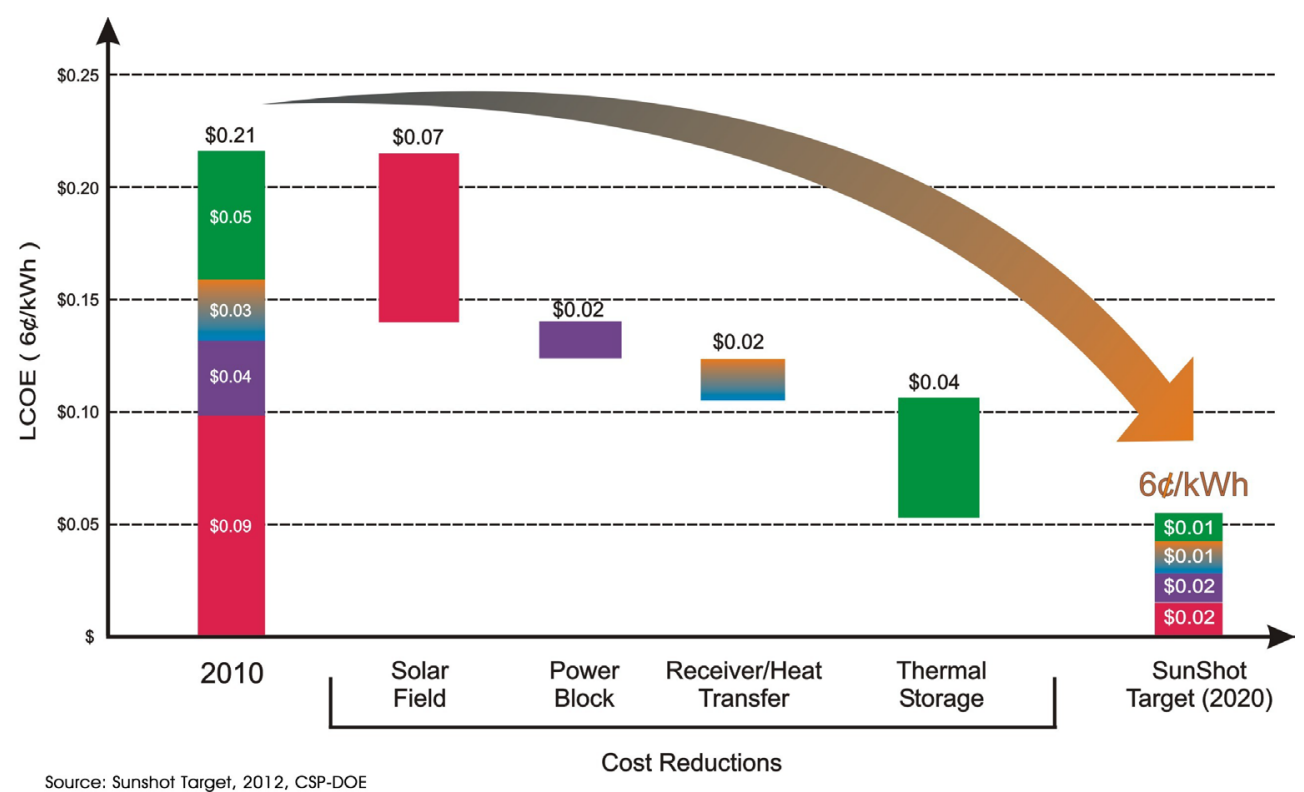

Figure 2. Cost of electricity generated as function of cumulative installed capacity (learning curve). Source: Sunshot Target (2014).

With the prospect of technological and commercial maturity of large-scale solar thermoelectric plants in the 2020s, it would be appropriate for the electrical system in Minas Gerais to follow the evolution of this technology, to perform $R \& D$ in detail, and to evaluate the potential of the solar resource available in its territory. In addition to its renewable aspect and its low environmental impact, the installation of solar thermal power plants is important regionally, due to the following aspects: a) it improves the "mix" of the Brazilian electricity generation sector and thus increases the security of the electrical system; b) the solar resource is the strongest in the dry period in the region, and therefore, it has complementary characteristics to the regional hydroelectric system; c) the solar resource is the maximum in the highest consumption period (summer); d) it has a characteristically distributed generation (another safety factor of the electrical system); e) it can be installed in semiarid regions with low population density and non-competitive lands for other nobler uses (for example, agriculture); and f) it generates employment and income.

\subsection{Sitting Study with GIS}

The use of GIS in renewable energy that began in the 1990s went through considerable progress, and, as a result, various decision support tools were developed [4]. The pioneering work regarding the use of GIS for CSP (Concentrated Solar Power) is due to [5] who analysed Northern Africa, providing a ranking of sites with respect to the potential and the cost of solar thermal electricity for a particular power plant configuration. Recently, this type of study has become widespread: [6] for the Southwest of the USA, [7] for South Africa, [8] for Oman, [9] for Burkina Faso, [10] for Australia [11] for India, and [12] based on the combination of a Geographic Information System (GIS) and multi-criteria decision making (MCDM), for Spain.

The assessment and identification of site using GIS are revolutionising the decision-making process in the world and decisively contribute to the rapid growth of the CSP technology implementation. Thus, in this work, the identification and mapping of the most promising places in Northeastern Brazil was performed so that the country may soon start the process of implementing CSP solar technology on a large scale.

\section{SEGS Thermoelectric Solar Plant}

As previously mentioned, solar generation technology based on parabolic cylindrical concentrators has been the technology that presently has had the highest cumulative amount of installation and the longest operational experience; thus, its technical and commercial reliability is clearly shown and is therefore the focus of this work.

The field of linear collectors of the SEGS has as its basic component the SCA capturing system (Solar Col- 
lector Assembly), which is curved glass mirrors forming a parabolic cylindrical cavity where the direct normal solar irradiation is focused. Each SCA is composed of an independent parabolic collector, metal support structure, receptor tubes and solar tracking system. Collectors are aligned on the North-South axis, allowing solar tracking according to the East-West axis, ensuring that the sun is continuously focused on the absorber tube.

Figure 3 shows a diagram of the typical configurations of SEGS-type stations. In the collector field of the station, a fluid is heated up to approximately $400^{\circ} \mathrm{C}$ and pumped through a series of heat exchangers, where superheated steam is generated. Then, the fluid returns to the system. The generated steam triggers a conventional turbine-generator set to produce electrical energy. The steam used by the turbine is later condensed and returns to the heat exchangers to be transformed again into steam, repeating the cycle.

\section{Geographic Information Systems}

According to [13] a Geographic Information System (GIS) is characterised as a set of techniques implemented in a computational environment that is able to manipulate, store, recover data and visualize in many ways that reveal news relationships, patterns, and trends.

Every GIS must have the following functionalities [14]: 1) descriptive and graphic data input; 2) data storage and managing; 3) interaction with the user; 4) data analysis elaboration; and 5) output information and presentation. The descriptive and graphic data input is a very relevant aspect, as it determines the information plans (geographic database storage basic units) to be used in a GIS application. When this phase is performed without knowledge of the cartographic fundamentals, chart inconsistencies might be created due to the conversion between CAD and GIS platforms, for example, the overlap of information plans in incompatible scales, the use of documents from distinct Reference Geodesic Systems, and so on. Data storage and management are treated by the DBMS (Database managing system), which must facilitate the input, output and recovery of spatial data, thus controlling and restricting access. Interaction with the user allows access to the GIS functionalities. This interaction must be easy to interpret, as the difficulties involving the interaction with the user are one of the causes of the systems' abandonment. Data analysis is made in the graphic bases-from spatial analysis—as well as in the descriptive one- by arithmetic calculations and Boolean logics, allowing the issuing of reports, graphics, and maps, among others. The output information may be implemented in a temporary or definite way. The former occurs when the information is presented in the monitor or stored in magnetic media while the latter when printed (analog media).

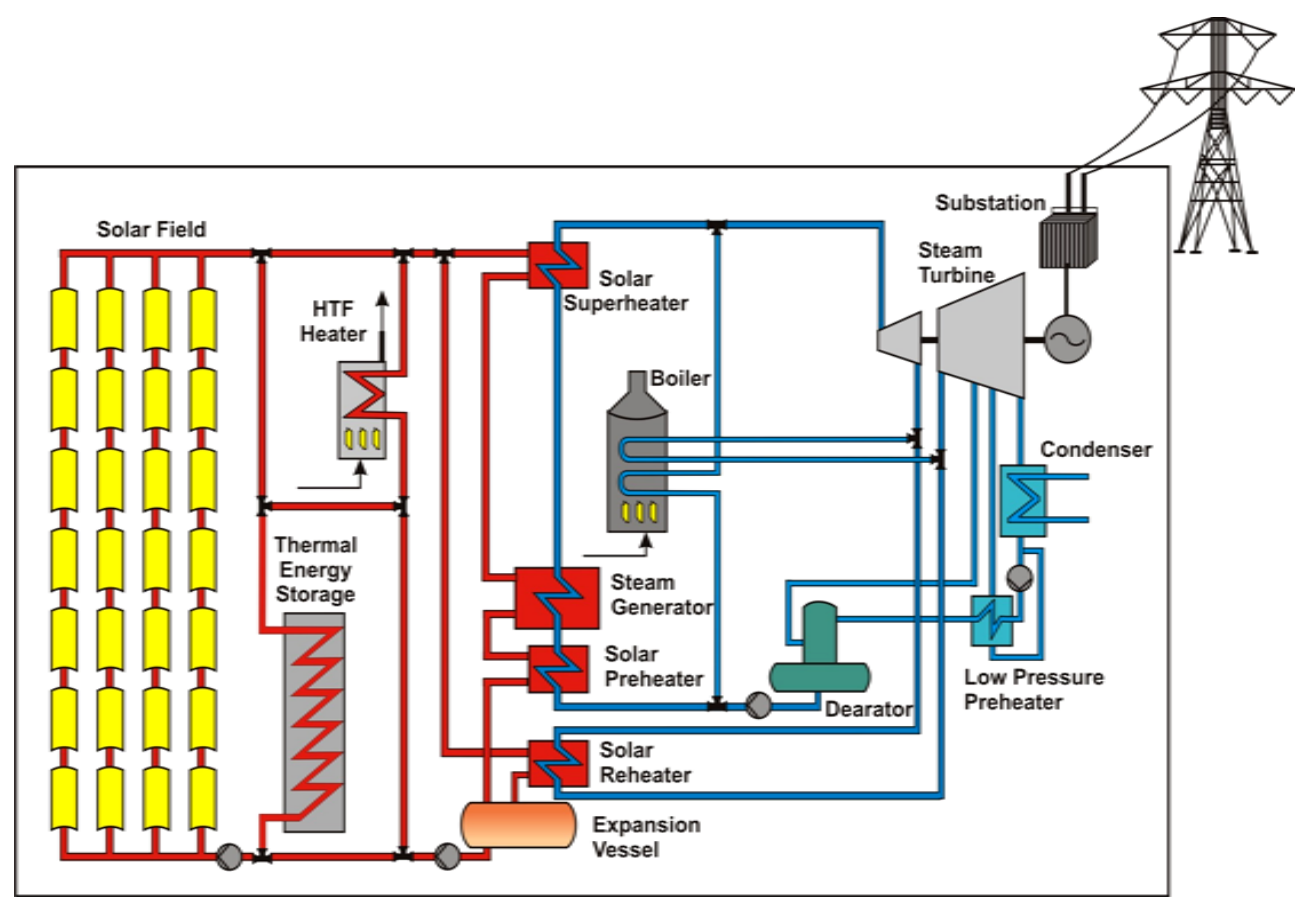

Figure 3. Typical configurations of SEGS type stations. Source: Solar Trough (2008). 


\subsection{Spatial Data in GIS}

Spatial data in GIS are composed of graphical and descriptive data. The former are responsible for the graphical records, which correspond to definite locations in the real world, and they can be stored or represented in the formats of a vector or matrix files (raster). The vector structure foresees the existence of three distinct spatial bodies represented in the geographic primitives: point, line and polygon. The raster, however, is a numerical structure represented by stored images in matrix format. The matrix is composed of a set of pixels (cells) disposed in lines $(\mathrm{x})$ and columns $(\mathrm{y})$. The matrix position $(\mathrm{x}, \mathrm{y})$ defines the image coordinates and exhibits an associated grey level.

The descriptive data are structured by sequential lines (records) or indexed files and include the attributes that describe the bodies of these objects. The descriptive data qualify the graphic data by means of attributes and are, generally speaking, stored in database table structures and controlled by the Database Managing System (DBMS).

The spatial data have four inseparable characteristics [13]: 1) geographic position; 2) associated attributes; 3) topologic relations; and 4) temporal reference. The geographic position responds to the "where is it?" question, and the attribute is a spatial data component that aims to describe and characterise the graphic feature, responding to the "what is it" and "what does it refer to" questions; the topologic relations describe the spatial relationships of the object and its peripheries, and the temporal reference involves the data behaviour assessment throughout time.

The GIS applications are usually in the form of two large spatial data: a) Geofields, which are used to represent spatial distributed values, such as, soil type, topography and mineral content; and b) Geographic objects, which are individualised and have a specific identification. The geographic objects (or geo-objects) have nonspatial attributes stored in a database. These objects might be associated with several graphic representations, such as schools, municipalities and farms.

\subsection{Spatial Analysis in GIS and Field Algebra}

The objective of the spatial analysis is to measure properties and relationships considering the spatial location of the studied phenomenon [15]. One of the main types of spatial analysis is field algebra. Field algebra (also known as map algebra) consists of a spatial analysis procedure set in GIS, which produces new data from the manipulation functions applied to it. The elements of the field algebra operate on maps, associating each place of a determined studied area to a quantitative or qualitative value. The maps are treated as individual variables, and the calculations defined on those variables are applied homogenously in all points of the map. According to [16], these calculations may be grouped into three classes: punctual, neighbours, and zone.

The punctual calculations result in numerical or thematic geo-fields, whose values are a function of the associated values to the same place by one or more representations of the other geo-fields. These calculations occur over maps (scanning of a numerical model of the land, for example) or over spatial sets (Boolean operations, for example), whether mathematical or transformational (pondering, scanning, among others).

The neighbor calculations act on a geo-field influenced by the neighbour dimension and shape (mask). During the calculation, the mask dislocates, applying to the geo-field the values of the attribute delimited by the mask. In the computational environment, the most used mask shape is that of a cell matrix. The spatial filtering of the geo-field, using image representations and slope calculations from an altimetry geo-field, is an example of neighbour operations using a mask in the cell matrix format [16].

In the zone calculations in field algebra, the value of each geographic position of the geo-field destination depends on the value of the attribute in all of the geographic positions that comprise the region in the initial geofield. Unlike the neighbour transformations, where each geographic position had its own neighbour, represented by a mask that dislocates over the data, in the zone transformation, the regions are static and do not dislocate over the geographic studied region. Examples of such calculations are the calculations of zone majority and zone diversity.

\section{Methodology}

The identification of the most favourable locations for the installation of large solar power plants, either photovoltaic or thermoelectric, previously required the procedures outlined in Figure 4. The procedures are applied 


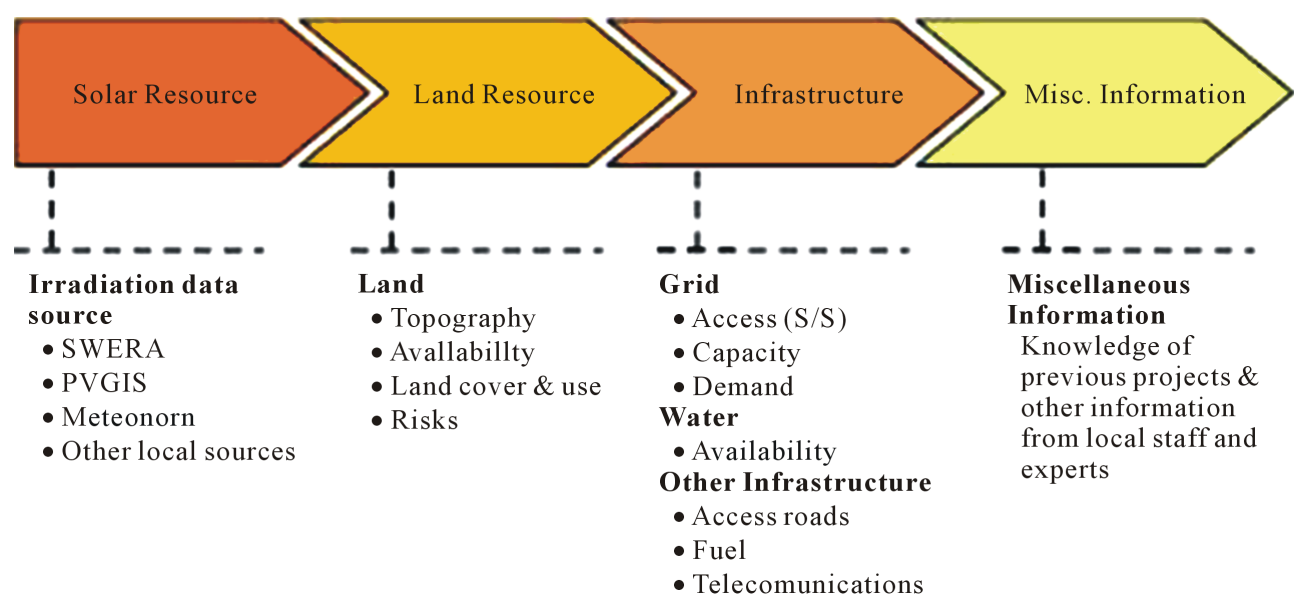

Figure 4. Flowchart of the procedures for the identification of the most favorable locations for the installations of large solar power plants. Source: EM Power Utility Toolkit, Large Scale Solar Power Trough (2010).

with the previously existing documentary information, and therefore, in a recommended second phase, on-site visits are made so that the ratification of such information is or is not implemented. For the set of sites resulting from this filtering, it is interesting to immediately start irradiation measurements in these locals because solar irradiation is the most relevant variable in the economy of the future endeavour.

Using irradiation measurements within at least 1 year (ideally more than 3 years) and taking into account all of the other items mentioned, the choice of the location of the solar power enterprise is made. In the case of solar power plants for electricity production using medium or high concentrations, sites with high direct solar irradiation are essential.

In sitting studies of large solar power plants, among others, the following variables are considered: solar resource global or direct according to the solar technology used: fixed or concentration; availability of land in a non-confrontational way (agricultural land, reserves or national parks, Indigenous reservations are exclusive); close proximity to access for transporting delicate or large equipment (mirrors); proximity to transmission lines; and availability of good quality water (dispensable for PV systems). Individually, the knowledge of the solar resource is the most relevant variable in the uncertainties associated with a solar energy system project.

\section{Procedures}

All of the aforementioned information is standardised in information plans (geo-referenced maps), which are crossed, therefore resulting in new and useful information for the identification of the most promising sites.

The following information plans were used for the initial identification of the most promising regions of the state:

- Direct normal solar irradiation (SWERA, 2005);

- Slope (SRTM);

- Water resources;

- Transmission line (CEMIG);

- Land use and occupation (EMBRAPA).

\section{Analysis and Diagnosis}

\subsection{Solar Resource}

A solar plant, whether thermal or photovoltaic, with concentration requires high incidence of direct normal solar irradiation because it uses (almost exclusively) only the direct portion of the solar irradiation falling onto its surface. According to Equation (1), the solar irradiation incident on the collection plane of the concentrator $\left(\mathrm{I}_{\mathrm{c}}\right)$ is determined by the direct normal component $\left(\mathrm{I}_{\mathrm{b}}\right)$ plus the diffuse component $\left(\mathrm{I}_{\mathrm{d}}\right)$ divided by the concentration (C). Then, in the solar plant where there is a concentration ratio of $50<\mathrm{C}<100$, which is typical, for example, 
of the commercial plant of cylindrical parabolic technology, the contribution of the diffuse component is negligible, that is, $I_{b}-I_{c}$. Therefore, to determine the best location of these plants, it is essential to characterise the direct normal solar irradiation.

$$
I_{c}=I_{b}+\frac{I_{d}}{C}
$$

For low concentration systems or plants, the direct normal solar irradiation is less critical, but even so, the prerequisite is still a good level of global solar irradiation, which usually occurs in regions where there is also too high incidence of direct solar irradiation.

A solar plant for the production of solar thermal electric is usually a high concentration system of solar irradiation, and therefore, favorable sites for their installation must have a solar irradiation $>2100 \mathrm{kWh} /\left(\mathrm{m}^{2} \cdot\right.$ year , or $>5.75 \mathrm{kWh} / \mathrm{m}^{2}$ day annual average. For flat photovoltaic systems (without concentration), the requirement is lower: the global solar irradiation should be $>2000 \mathrm{kWh} /\left(\mathrm{m}^{2} \cdot\right.$ year $)$, i.e., $>5.5 \mathrm{kWh} / \mathrm{m}^{2} \cdot$ day annual average. These values are slightly higher than the ones usually used for the preparation of feasibility studies for the installation of photovoltaic or thermoelectric plants in the world.

The state of Minas Gerais has vast regions fulfilling the aforementioned criteria. In Figure 5, it can be seen that half of the state, more precisely the entire western side, has a daily global solar irradiation average in the range of 5.5 to $6.5 \mathrm{kWh} / \mathrm{m}^{2}$.day. For the daily normal direct solar irradiation, the annual average for the entire western side of the state satisfies this condition, as shown in Figure 6.

\subsection{Availability and Topography}

The cylindrical parabolic concentrators require relatively large areas. A solar power plant consisting of 80 MWe

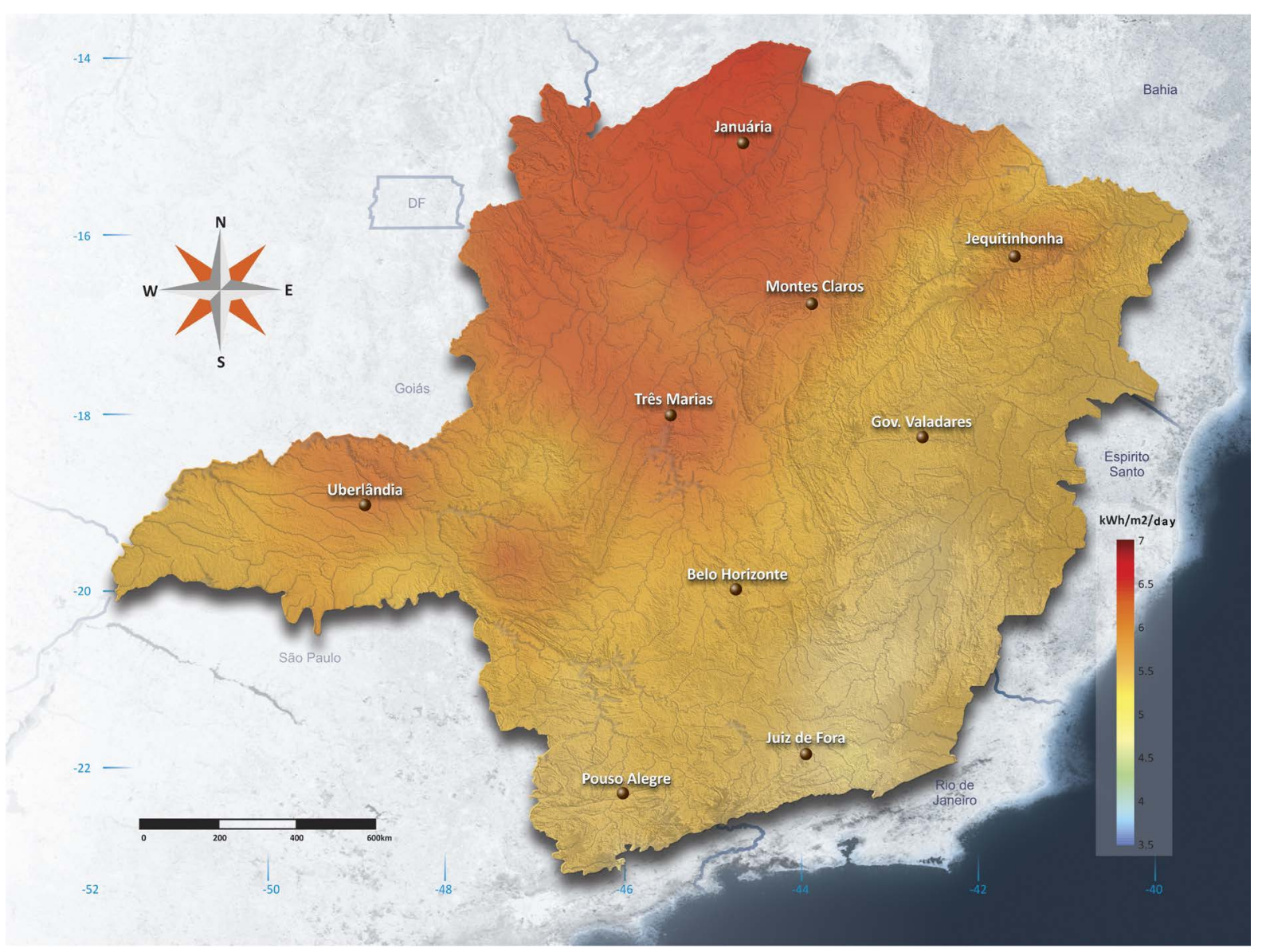

Figure 5. Global daily solar irradiation annual average for the state of Minas Gerais. 


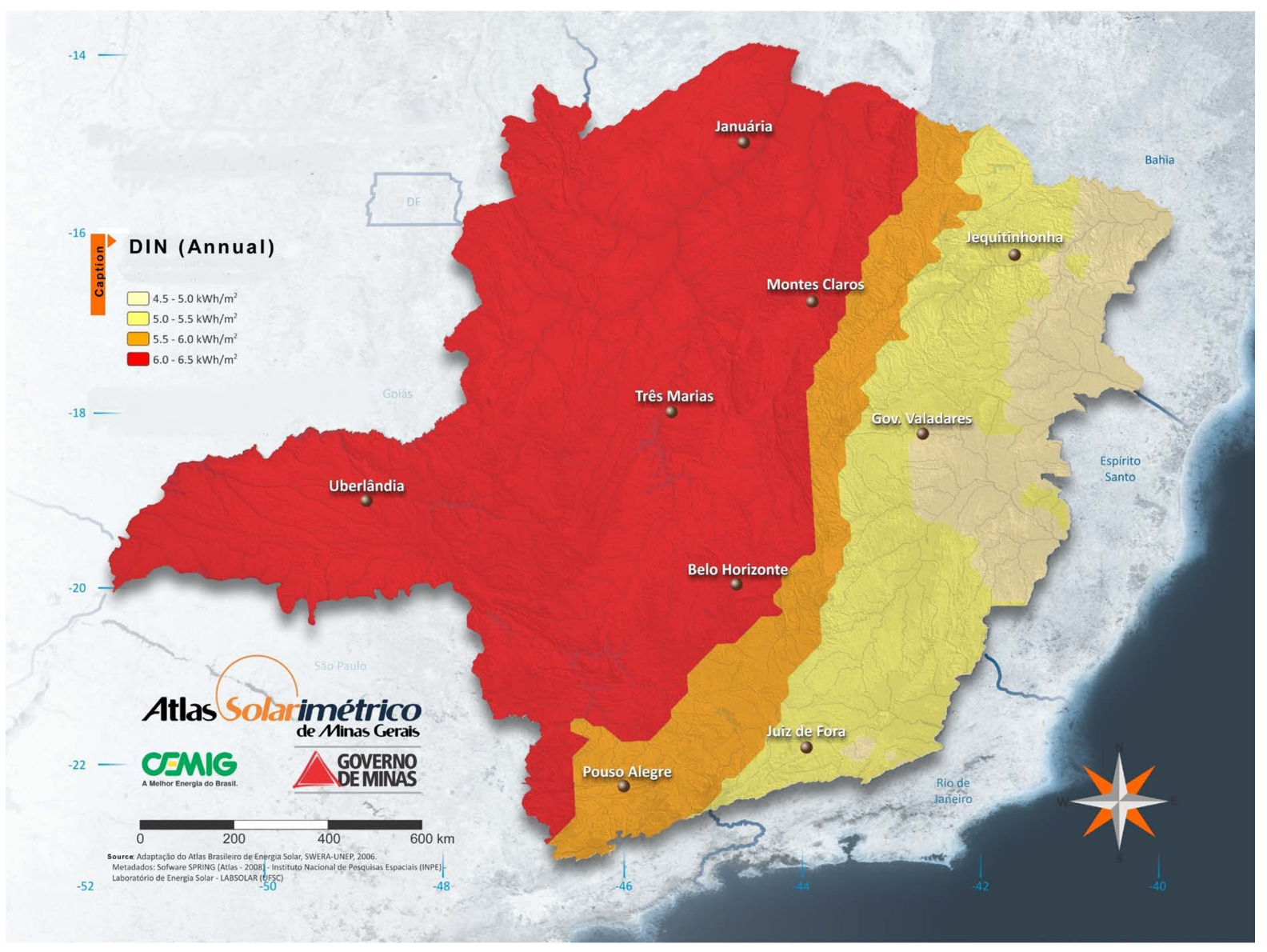

Figure 6. Daily direct solar irradiation annual average for the state of Minas Gerais.

requires approximately 500,000 $\mathrm{m}^{2}$ (without considering the thermal storage) to accommodate the arrangement of the collectors. The scaling factor derived from the experiences of the construction of solar power plants indicates that it is advantageous to install several adjacent plants, thereby forming a solar park. Thus, the minimum area availability could be $2-8 \mathrm{~km}^{2}$ for successive modular installation of these plants.

The topography of the land where the solar plant will be located determines the acceptability of the site according to its impact on the relative cost for the preparation and levelling of the land. This location must be as flat as possible (with slopes less than 2\%) but sufficient to allow the natural drainage of the land.

Regarding the visual horizon of the field of collectors, only obstructions (such as hills, trees, towers, or others) whose visual angles are less than 100 are allowed.

In Figure 7, the slopes in the state are shown. Continuous regions of low slope $(<3 \%)$ can be identified ("patches") in the Northwest of Minas Gerais, in the region of Januária, and in Janaúba and Capão Redondo. The solar photovoltaic plants are much less demanding in terms of slope because they are more modular. The slopes in the range of 3\% - 8\% are acceptable; thus, some additional regions in the Northwest, the Central Western region of Belo Horizonte, and the extreme West satisfy such prerequisites.

\subsection{Use and Occupation}

In the implementation of a solar plant, permits and any restrictions on land use should be considered. Permissions relate to the issues of the contractual relationship between the landowners and the project developers, while the restrictions refer to the intended use of the ground. In this regard, it is noted that in urban areas or urban expansion, Environmental Protected Areas (EPAs, Figure 8), areas of food production (arable, Figure 9), and former slave (quilombolas) and indigenous territories, for example, are considered unsuitable regions for installing solar plants. The dry and arid regions are considered typical for the installation of these plants. 


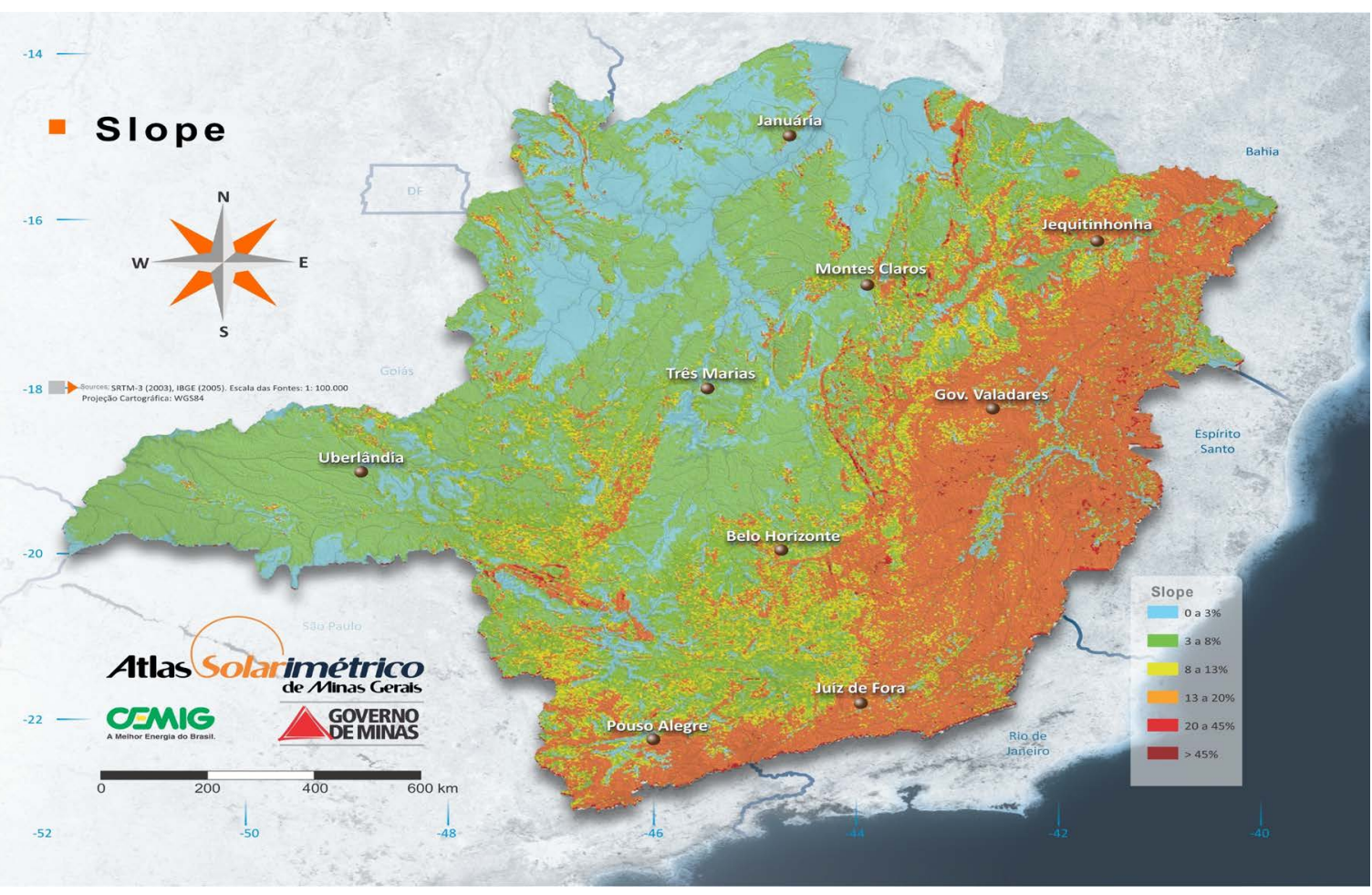

Figure 7. Slope of the land in the state of Minas Gerais.

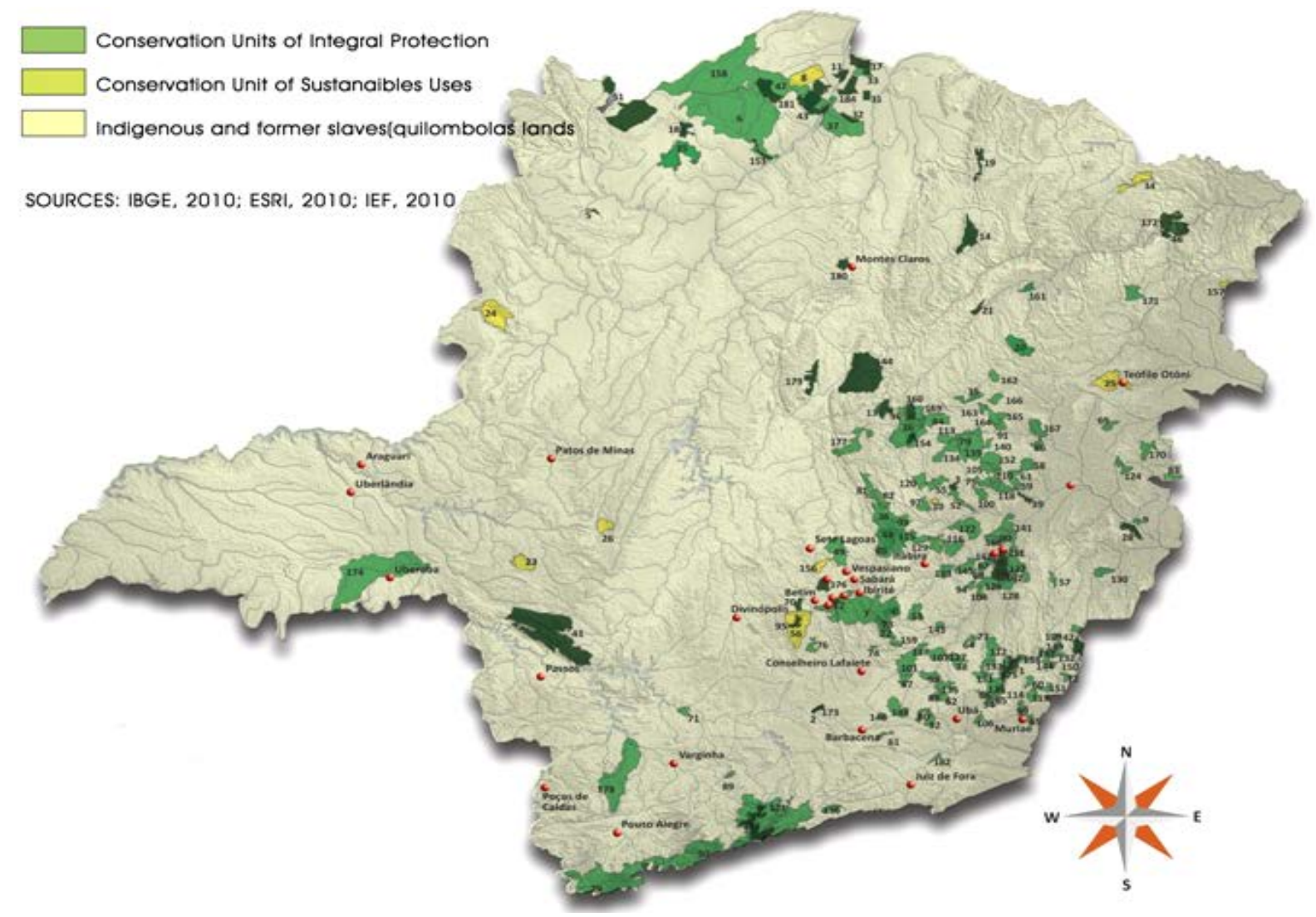

Figure 8. Enviromental Protection Areas (EPAs). 
AGRICULTURAL POTENTIAL MAP
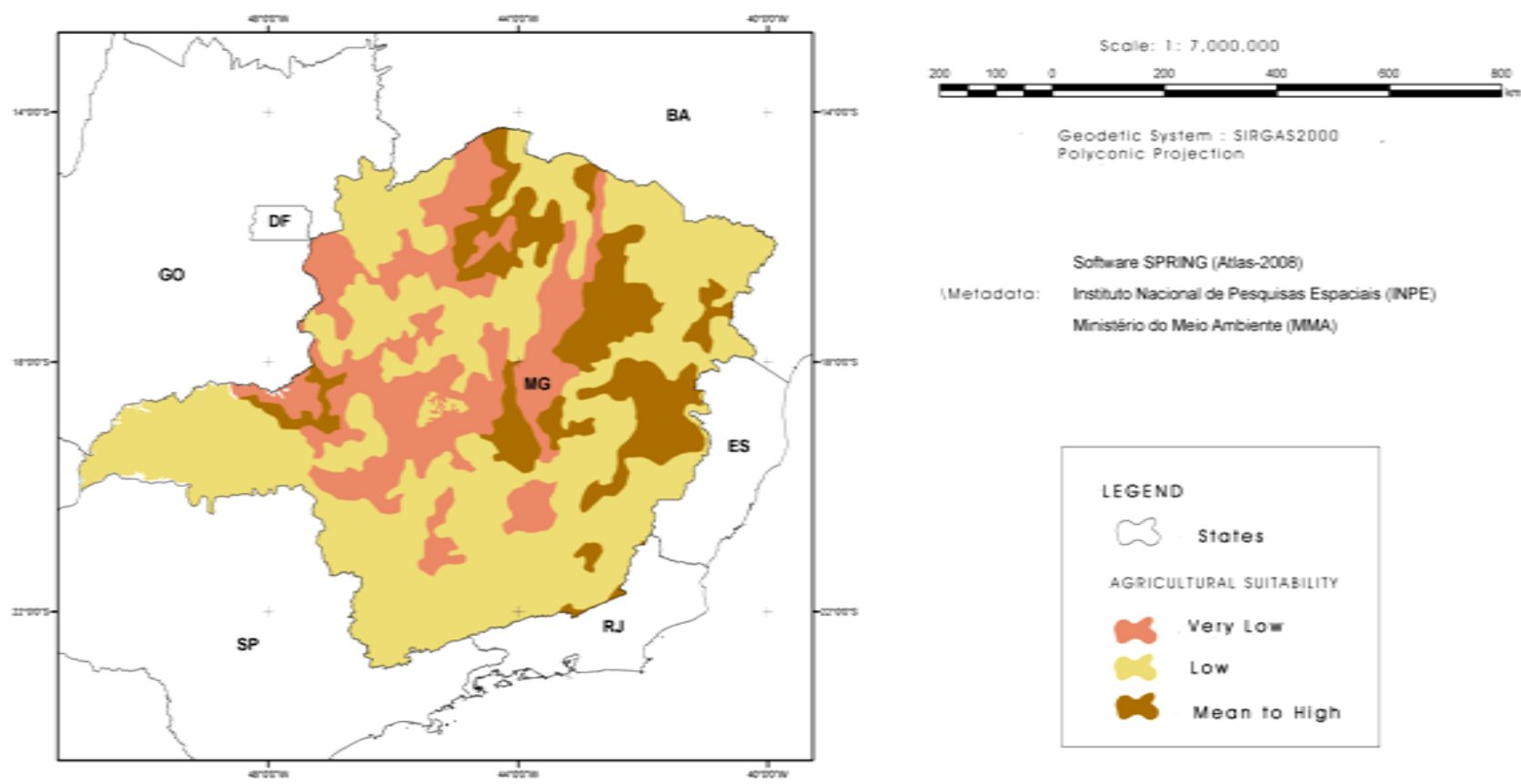

Sofware SPRING (Allas-2008)
(Metodato: Insticato Nacional de Pesquisas Espaciais (NPE)

Mristerio do Maio Ambiente (MMA)

Figure 9. Land suitability in the state of Minas Gerais.

\subsection{Risks}

Natural disasters, such as earthquakes, strong gusts of wind, sand storms, hail, lightning, and other factors, are potential damaging factors or disruptive factors to the operation of solar power plants. Moreover, soil quality should also be considered.

\subsection{Connection to the Electricity Network}

The requirements for connection to the electrical grid for a solar plant that uses parabolic cylindrical collectors are similar to other steam power plants. A plant that produces 80 MWe of power, for example, must have 230 $\mathrm{kV}$ of transmission lines. In addition to charge capacity, another important aspect should be considered: the distance between the solar plant and transmission lines. The actual costs with the construction of new transmission lines are generally very high and depend on the voltage level of the line and its length. Thus, the solar plant must be positioned as close as possible to the transmission lines. Figure $\mathbf{1 0}$ shows the transmission lines that cross the state of Minas Gerais.

\subsection{Water Supply}

A 50 MWe parabolic cylinder power plant operating 350 days a year and 10 hours per day, for example, uses approximately $500,000 \mathrm{~m}^{3}$ of water or $1500 \mathrm{~m}^{3} /$ day. This water is required for the cooling towers (90\%), steam generation in a power cycle (8\%), and the cleaning of the mirrors (2\%). The typical flow for the cooling tower is $320 \mathrm{~m}^{3} / \mathrm{h}$. The water must also have adequate quality to prevent oxidation and incrustations of the equipment.

In general, the state of Minas Gerais is well supplied with water. Consequently, this aspect will not be restrictive for the installation of large solar power plants. Note that the solar photovoltaic plants require only a small amount of water, mainly for cleaning of the modules and for removing the dust and other contaminants.

\subsection{Availability of Fuel or Other Backup Energy Sources}

Fuels or other backup energy sources are required for the hybrid operation of the solar plant (solar resource + fuel). In solar cylindrical parabolic plants abroad, natural gas is used as a backup fuel. In the semiarid region of Minas Gerais, recent announcements indicate a good occurrence of gas, which is very promising. 


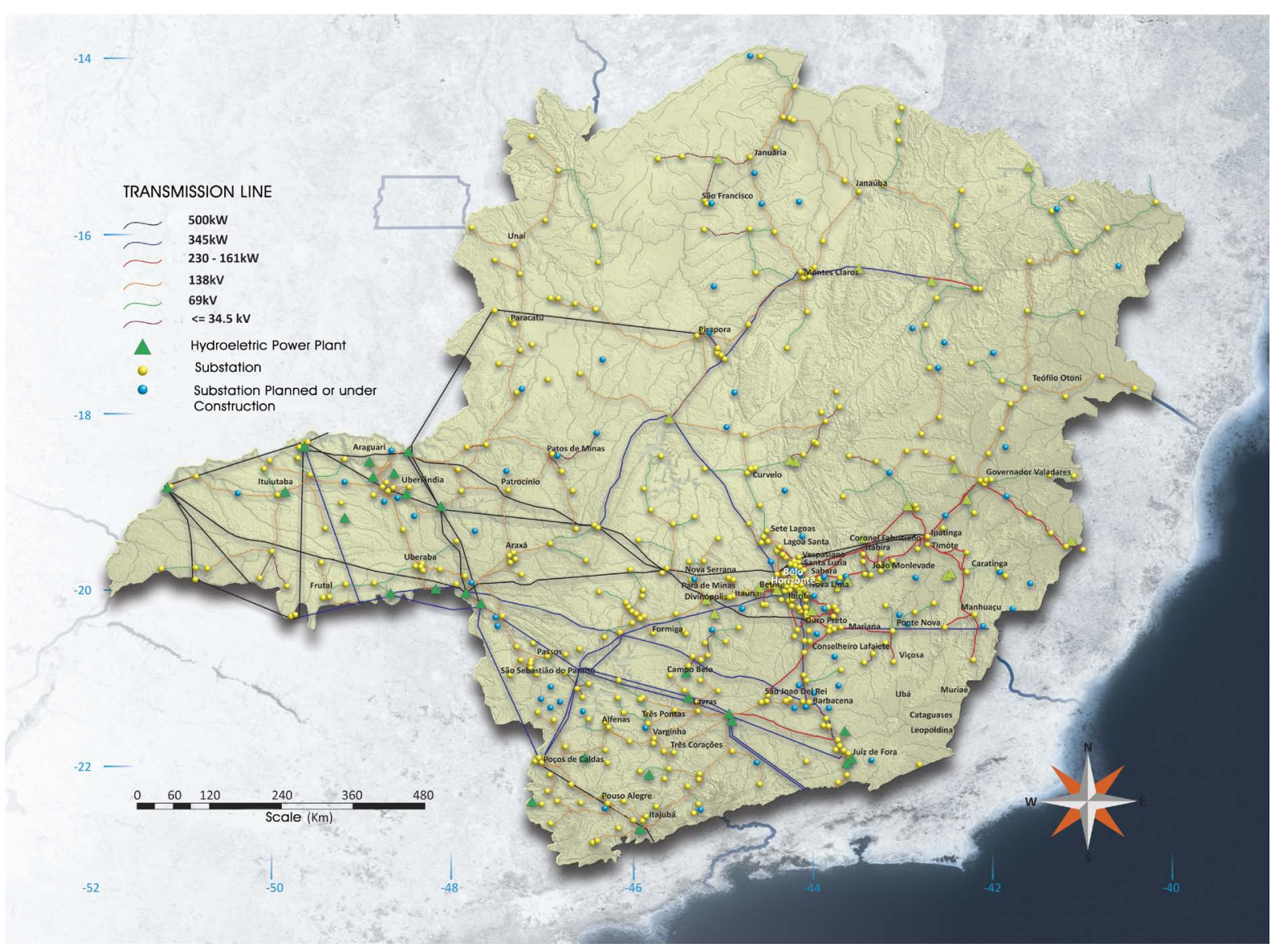

Figure 10. Existing transmission line in the state of Minas Gerais.

\subsection{Access}

Access to the site is relevant to transport large and fragile equipment (glass mirrors). The criteria for classifying the access are the widths of the roads, the road surface quality and the possibilities for manoeuvring large vehicles. According to the Department of Highways of Minas Gerais the state has $8957 \mathrm{~km}$ of federal highways (only $667 \mathrm{~km}$ unpaved) and 26,604 km of state highways (7238 km unpaved, Figure 11). As far as the rail network is concerned, Minas Gerais has $5080 \mathrm{~km}$ of railways, and the major companies operating in the sector are Centro-Atlântica, MRS Logistica S.A., and Estrada de Ferro Vitoria a Minas. Furthermore, Minas Gerais has navigable rivers, such as the Paranaíba, Paracatu, Velhas, Paraopeba and São Francisco rivers.

\subsection{Identification and Prioritization of Sites}

Considering the relevant aspects mentioned above, and taking as a reference the limits of micro-regions defined by the IBGE, it can be said that the classification of the most promising areas in the state of Minas Gerais are those shown in Figure 12:

\subsubsection{Area 1-Micro-Region of Janaúba}

Micro region of Janaúba is one of the micro-region of Minas Gerais, belonging to the meso-region of the Northern Minas. According to the 2010 Demographic Census, its population was 273,275 inhabitants [17], and it is divided into 13 municipalities, where Janaúba, Jaíba and Espinosa are highlighted, having a total area of $15155.227 \mathrm{~km}^{2}$ [17]. Undoubtedly, the region is the most gifted direct normal solar irradiation area in Minas Gerais, with annual values of $2200-2400 \mathrm{kWh} / \mathrm{m}^{2}$, reaching up to $2500-2700 \mathrm{kWh} / \mathrm{m}^{2}$ in the summer.

Most of the territory has low agricultural potential, low slopes and a lack of protected units. The municipalities of Espinosa and Mocambinho, located in this micro-region, exhibit the highest values of direct normal solar 


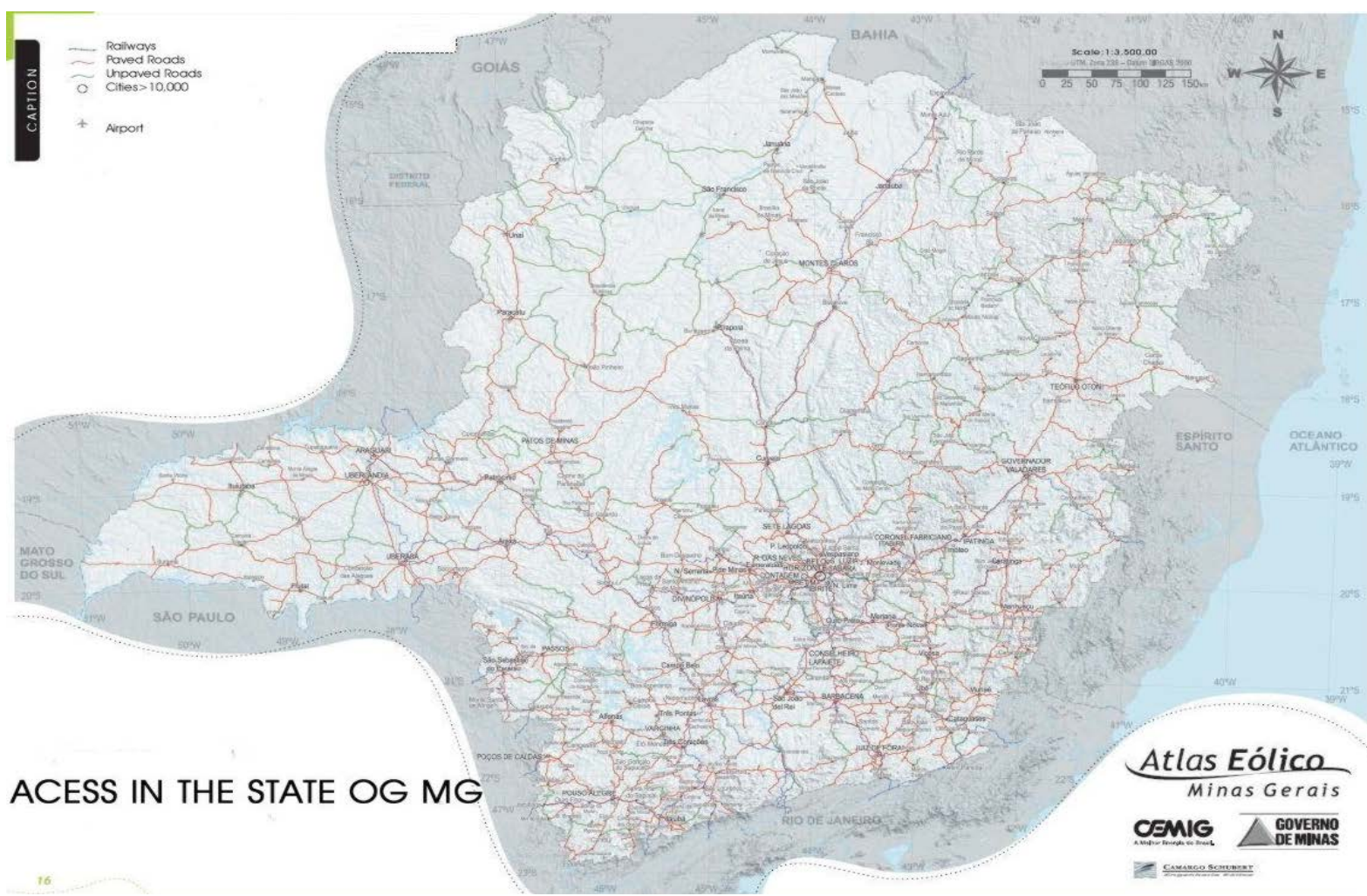

Figure 11. Access in the state of Minas Gerais.

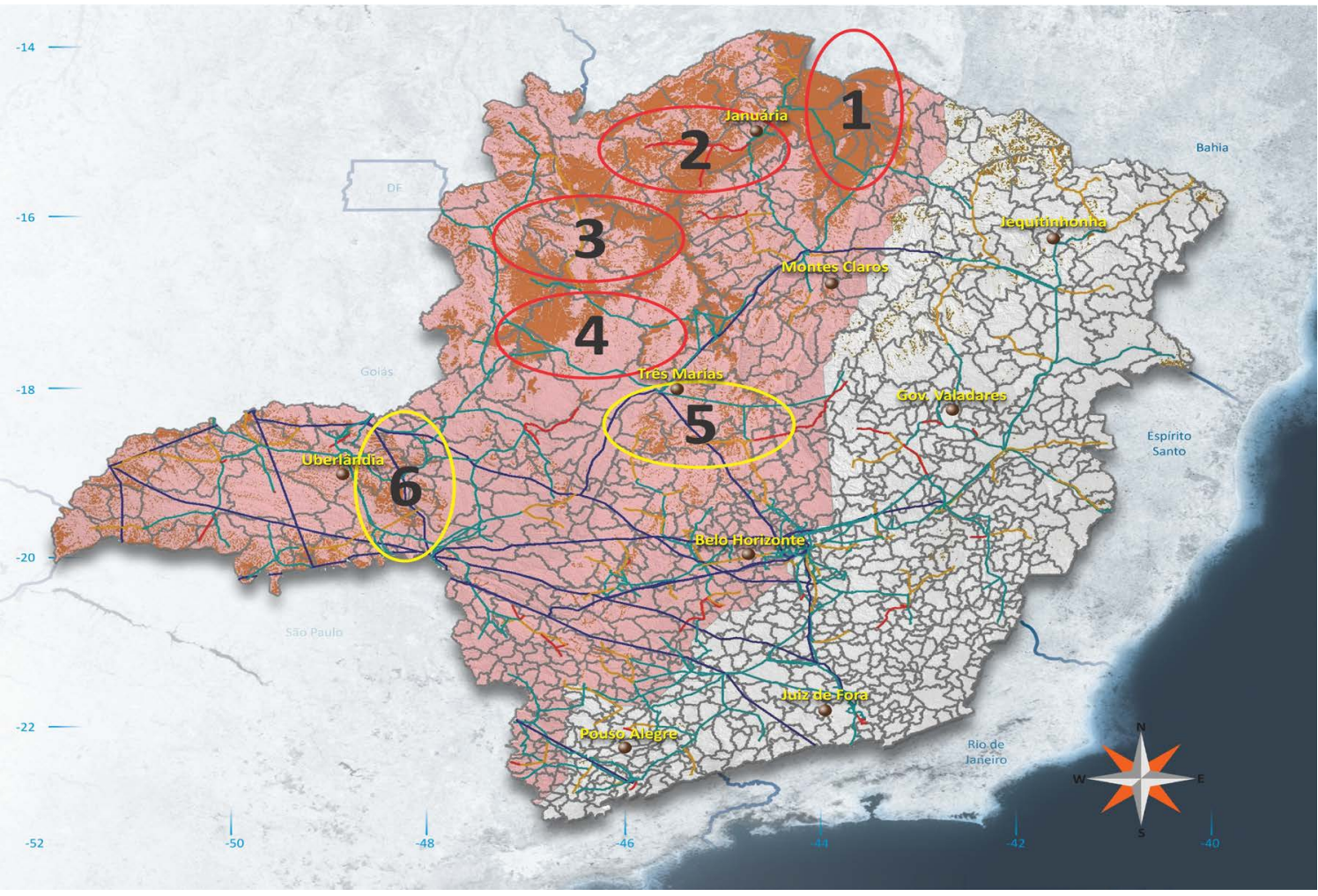

Figure 12. Promising regions of Minas Gerais according to intersections of direct daily solar irradiation, slope and transmission lines. 
irradiation in the state of Minas Gerais. The major consumption centres of Area 1 are in the municipalities of Janaúba, Jaíba and Espinosa, with approximately 66,000, 33,000 and 31,000 inhabitants [17], respectively. The Janaúba micro-region had an invoiced consumption in 2010 (by CEMIG) of 240 GWh [18].

\subsubsection{Area 2-Micro-Region of Januária}

The micro-region of Januária is one of the micro-regions of Minas Gerais, belonging to the Northern Minas meso-region. The population of Januária, According to the 2010 Demographic Census, its population was 254,055 inhabitants [17], and it is divided into sixteen municipalities in which Januária and San Francisco are highlighted. The micro-region has a total area of $33169.626 \mathrm{~km}^{2}$ [17]. Januária is also a well-endowed area regarding direct normal solar irradiation in Minas Gerais, with annual values of $2200-2400 \mathrm{kWh} / \mathrm{m}^{2}$, reaching $2500-2700 \mathrm{kWh} / \mathrm{m}^{2}$ in the summer in some parts of its territory. It is important to stress that in this region, there are areas of medium-to-high agricultural suitability and also protected units. Regarding the aspect of the slope, the regions exhibit a continuity slope $(<3 \%)$ smaller compared to those of Area 1 . In the Northern portion of Januária, there are minor restrictions on the aspects mentioned above. Furthermore, note that the town of Montalvânia, located to the North of that micro-region, exhibits the highest levels of direct normal solar irradiation. The largest consuming centres of area 2 are the cities of Januária and San Francisco, with approximately 65,000 and 53,000 inhabitants [17]. The micro-region of Januária had an invoiced consumption in 2010 (by CEMIG) of 147 GWh [18].

\subsubsection{Area 3-Micro-Regions of Pirapora and Unai}

Area 3, as identified, consists of two regions: the Southern portion of the micro-region Unai and the Northern portion of Pirapora, both belonging to the meso-region of the Northern Minas Gerais. The micro-region of Pirapora has a total area of $23071.697 \mathrm{~km}^{2}$ [17]. The main towns are Pirapora and Várzea da Palma, with approximately 53,000 and 35,000 inhabitants [17], respectively. The total population of the micro-region in 2010, according to the demographic census, was 164,941 inhabitants [17]. The micro-region of Unaí in 2010, according to the census, had a population of 148,829 inhabitants and is divided into nine districts. The micro-region has a total area of $27383.810 \mathrm{~km}^{2}$. The main towns are Unaí and Buritis, with approximately 77,000 and 22,000 inhabitants, respectively. Area 3 has solar direct normal irradiation with annual values of $2200-2400 \mathrm{kWh} / \mathrm{m}^{2}$, and much of the territory has low or very low agricultural potential and the absence of Protected Units and Indigenous Territory. Regarding declivities, that area is worse than the first one, as the density of the continuous regions of low declivities, i.e., less than $3 \%$, is smaller. Nevertheless, it is a region with reasonable slopes. Note again that the municipality of São Romão, which is located North of the micro-region of Pirapora, is one of the regions with higher levels of total solar irradiation. Together, these two micro-regions had an invoiced consumption in 2011 (by CEMIG) of 2989 GWh [18].

\subsubsection{Area 4-Micro-Regions of Pirapora and Paracatu}

Area 4 consists of parts of two micro-regions: the Southern portion of the micro-region Pirapora and the microregion of Paracatu. Paracatu is one of the micro-regions of Minas Gerais that belongs to the middle region of the Northwest of Minas Gerais and has a total area of $34997.251 \mathrm{~km}^{2}$. According to the demographic Census in 2010, it had approximately 217,555 inhabitants. The main municipalities are Paracatu and João Pinheiro, with approximately 84,000 and 45,000 inhabitants [17], respectively. The description of the micro-region of Pirapora is provided above. These regions have a direct normal solar irradiation in the state of Minas Gerais, with annual values of $2200-2400 \mathrm{kWh} / \mathrm{m}^{2}$. Most of area 4 has low or very low agricultural potential and the absence of protected areas and indigenous territories. The slope, mainly in the micro-region of Paracatu, is quite favourable, not only for its extension but also for its continuity. Together, these two micro-regions had an invoiced consumption in of 3323 GWhA [18].

\subsubsection{Area 5-Micro-Regions of Curvelo and Três Marias}

Area 5 is composed of parts of two micro-regions: the micro-region of Curvelo and the micro-region of Three Marias, both belonging to the Minas Gerais Central meso-region. This micro-region has a total of 13749.120 $\mathrm{km}^{2}$ and approximately 150,661 inhabitants. The main towns are Curvelo and Corinto, with approximately 7000 and 23,000 inhabitants, respectively [17]. The micro-region of Três Marias has a total area of $10509.238 \mathrm{~km}^{2}$ and 95,900 inhabitants. The main towns are Três Marias and Pompeu, both with approximately 29,000 inhabi- 
tants. These regions have direct normal solar irradiation in the state of Minas Gerais, with annual values of 2200 - $2400 \mathrm{kWh} / \mathrm{m}^{2}$. The micro-region of Curvelo has areas of middle and high agricultural suitability; however, there are no protected units or indigenous territories. There are sites, wherein the slopes are low, but as far as the total area is concerned, as well as the discontinuity, they are worse than the other areas previously analysed. The micro-region of Três Marias also follows this pattern, but it is noticeable that there are larger areas of low slope. However, these micro-regions have a higher density of transmission lines and are much closer to major consumption centres, such as Sete Lagoas and Belo Horizonte (170 Km of BH). The main centres of local consumers consist of the municipalities of Diamantina (44,000 inhabitants, $39 \mathrm{GWh}$ ) and Curvelo (72,000 inhabitants, $78 \mathrm{GWh}$ ). The region is crossed by transmission lines of $138 \mathrm{kV}$ and $34.5 \mathrm{kV}$ and the BR-259, BR-367 and MG-220 highways.

\subsubsection{Area 6-Micro-Regions of Patrocínio and Araxá}

Area 6 consists of part of two micro-regions: the micro-region of Patrocínio and the micro-region of Araxá, both belonging to the Triângulo Mineiro and the Alto Parnaíba meso-regions. The micro-region of Patrocínio has a total area of $11980.072 \mathrm{~km}^{2}$ and approximately 197,806 inhabitants [17]. The main towns are Patrocínio and Monte Carmelo, with approximately 82,000 and 50,000 inhabitants, respectively. The micro-region of Araxá has a total area of 14,103 $\mathrm{km}^{2}$ and 201,585 inhabitants [17]. The main towns are Araxá and Sacramento, with approximately 93,000 and 23,000 inhabitants, respectively. These regions have a direct normal solar irradiation in the state of Minas Gerais, with annual values between 2200 and $2400 \mathrm{kWh} / \mathrm{m}^{2}$. However, there are protected units in the micro-region of Araxá, and the micro-region of Patrocínio has places with middle and high agricultural suitability and no protected units or indigenous territory. In general, there are regions wherein the slopes are low; however, regarding both the total area and the discontinuity, they are similar to Area 5. Note that this micro-region has a higher density of transmission lines and is also much closer to major consumer centres, such as Uberlandia and Uberaba (154 km from Uberlândia, for example). Micro-regions 5 and 6 have lower amounts of flat regions but have the greatest advantage of being closer to major electricity-consuming centres and also of being in the interior of a region with the highest density of transmission lines.

\section{Conclusions}

The study identified a very promising potential for solar power generation either thermal or photovoltaic, reaching an annual direct solar irradiation of $2700 \mathrm{kWh} / \mathrm{m}^{2}$ in the summer, with 2200 to $2400 \mathrm{kWh} / \mathrm{m}^{2}$ on an annual basis. This region comprises a vast region in the North/Northeast part of the state. Equally, the region has very flat and continuous regions with less than $3 \%$ slope and an availability of good quality water resources (abundant and well distributed). This region has relatively few areas with high agriculture suitability and few protected units. In general, coverage of transmission lines of this region is adequate, with a higher density in the South and Southwest of the state.

This analysis is the first macro-spatial approach aiming to identify the most promising locations for solar energy development. A more detailed economic feasibility analysis will require a local assessment of solar irradiation for at least 3 years and a visit to the site to deepen and detail other aspects involved in the problem: slope, access, and the existence of transmission lines, among others.

In addition to the previously mentioned areas, there are other smaller extension ones that are sufficient for the installation of large solar plants. Such developments could be better located regarding access, proximity to transmission lines and consumption centres, although they are the worst in terms of the slope and competition with medium and high agricultural land suitability. A more detailed analysis of the cost-effectiveness for plants located in those regions should be made in the future.

Finally, it should be noted that this potential can be explored gradually in the medium term, due to the reduction of other energy sources, and the increasing readiness of these technologies and the creation of a complex solar-wind-hydro system that leverages the strong temporal complementarily of such resources, as has been observed.

\section{Acknowledgements}

We acknowledge CEMIG (Centrais Elétricas de Minas Gerais), ANEEL (Agência Nacional de Energia Elétrica) and the National Research Council (CNPq) for the support in the solar energy research studies, particularly re- 
garding the themes referring to measurements, evaluation and solar irradiation mapping.

\section{References}

[1] Tiba, C. and Reis, R. (2012) Solarimetric Atlas for Minas Gerais. 1st Edition, 80 p.

[2] Wikipedia (2012) http://en.wikipedia.org/wiki/List_of_solar_thermal_power_stations\#Operational

[3] Sunshot Target (2014) http://energy.gov/eere/sunshot/concentrating-solar-power

[4] Bravo, J.D. (2002) Los Sistemas de Información Geográfica en la Planificación e Integración de Energías Renovables. Editorial CIEMAT, Madrid.

[5] Broesamle, H., Mannstein, H., Schillings, C. and Tieb, F. (2001) Assessment of Solar Electricity Potentials in North Africa Based on Satellite Data and a Geographic Information System. Solar Energy, 70, 1-12. http://dx.doi.org/10.1016/S0038-092X(00)00126-2

[6] Mehos, M. and Owens, B. (2004) An Analysis of Sitting Opportunities for Concentrating Solar Power Plants in the Southwestern United States. World Renewable Energy Conference VIII, Denver, 29 August-4 September 2004.

[7] Fluri, T.P. (2009) The Potential of Concentrating Solar Power in South Africa. Energy Policy, 37, 5075-5080. http://dx.doi.org/10.1016/j.enpol.2009.07.017

[8] Charabi, Y. and Gastli, A. (2010) GIS Assessment of Large CSP Plant in Duqum, Oman. Renewable and Sustainable Energy Reviews, 14, 835-841. http://dx.doi.org/10.1016/j.rser.2009.08.019

[9] Azoumah, Y., Ramde, E.W., Tapsoba, G. and Thiam, S. (2010) Siting Guidelines for Concentrating Solar Power Plants in the Sahel: Case Study of Burkina Faso. Solar Energy, 84, 1545-1553. http://dx.doi.org/10.1016/j.solener.2010.05.019

[10] Clifton, J. and Boruff, B. (2010) Assessing the Potential for Concentrated Solar Power Development in Rural Australia. Energy Policy, 38, 5272-5280. http://dx.doi.org/10.1016/j.enpol.2010.05.036

[11] Purohit, I. and Purohit, H. (2010) Techno-Economic Evaluation of Concentrating Solar Power Generation in India. Energy Policy, 38, 3015-3029. http://dx.doi.org/10.1016/j.enpol.2010.01.041

[12] Sánchez-Lozano, J.M., Antunes, C.H., Socorro García-Cascales, M. and Dias, L.C. (2014) GIS-Based Photovoltaic Solar Farms Site Selection Using ELECTRE-TRI: Evaluating the Case for Torre Pacheco, Murcia, Southeast of Spain. Renewable Energy, 66, 478-494. http://dx.doi.org/10.1016/j.renene.2013.12.038

[13] Burrough, P.A. and Mcdonnel, R.A. (1998) Principles of Geographical Information Systems. 2nd Edition, Clarendon Press, Oxford, 311 p.

[14] Câmara, G., Casanova, M.A., Hermely, A.S., Magalhães, G.C. and Medeiros, M.B. (1996) Anatomia de Sistemas de Informações Geográficas. Cartgraf LTDA, 187 p.

[15] Goodchild, M.F. and Haining, R.P. (2004) GIS and Spatial Data Analysis: Covering Perspectives. Papers in Regional Science, 83, 363-385. http://dx.doi.org/10.1007/s10110-003-0190-y

[16] Barbosa, C.C.F. (1997) Álgebra de Mapas e suas Aplicações em Sensoriamento Remoto e Geoprocessamento. Dissertação de Mestrado, INPE, São José dos Campos.

[17] IBGE. http://www.cidades.ibge.gov.br

[18] CEMIG (2011) 250 Balanço Energético de Minas Gerais, 1984-1985 e 2009-2011. 
Scientific Research Publishing (SCIRP) is one of the largest Open Access journal publishers. It is currently publishing more than 200 open access, online, peer-reviewed journals covering a wide range of academic disciplines. SCIRP serves the worldwide academic communities and contributes to the progress and application of science with its publication.

Other selected journals from SCIRP are listed as below. Submit your manuscript to us via either submit@scirp.org or Online Submission Portal.
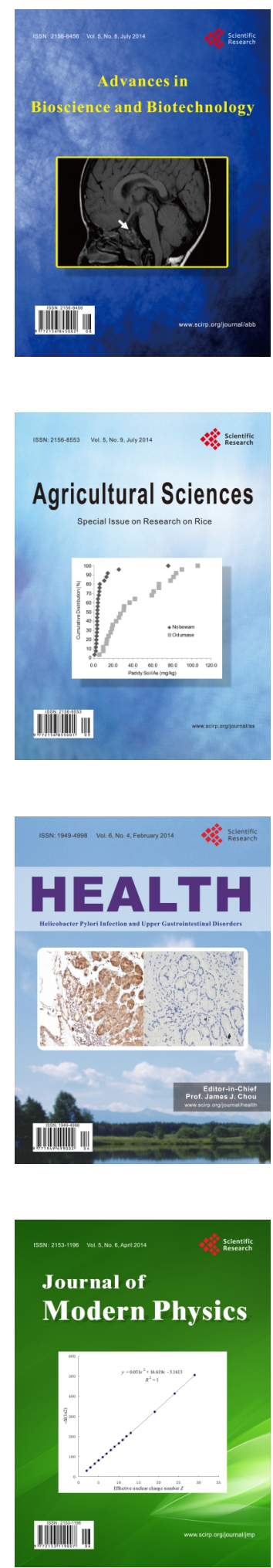
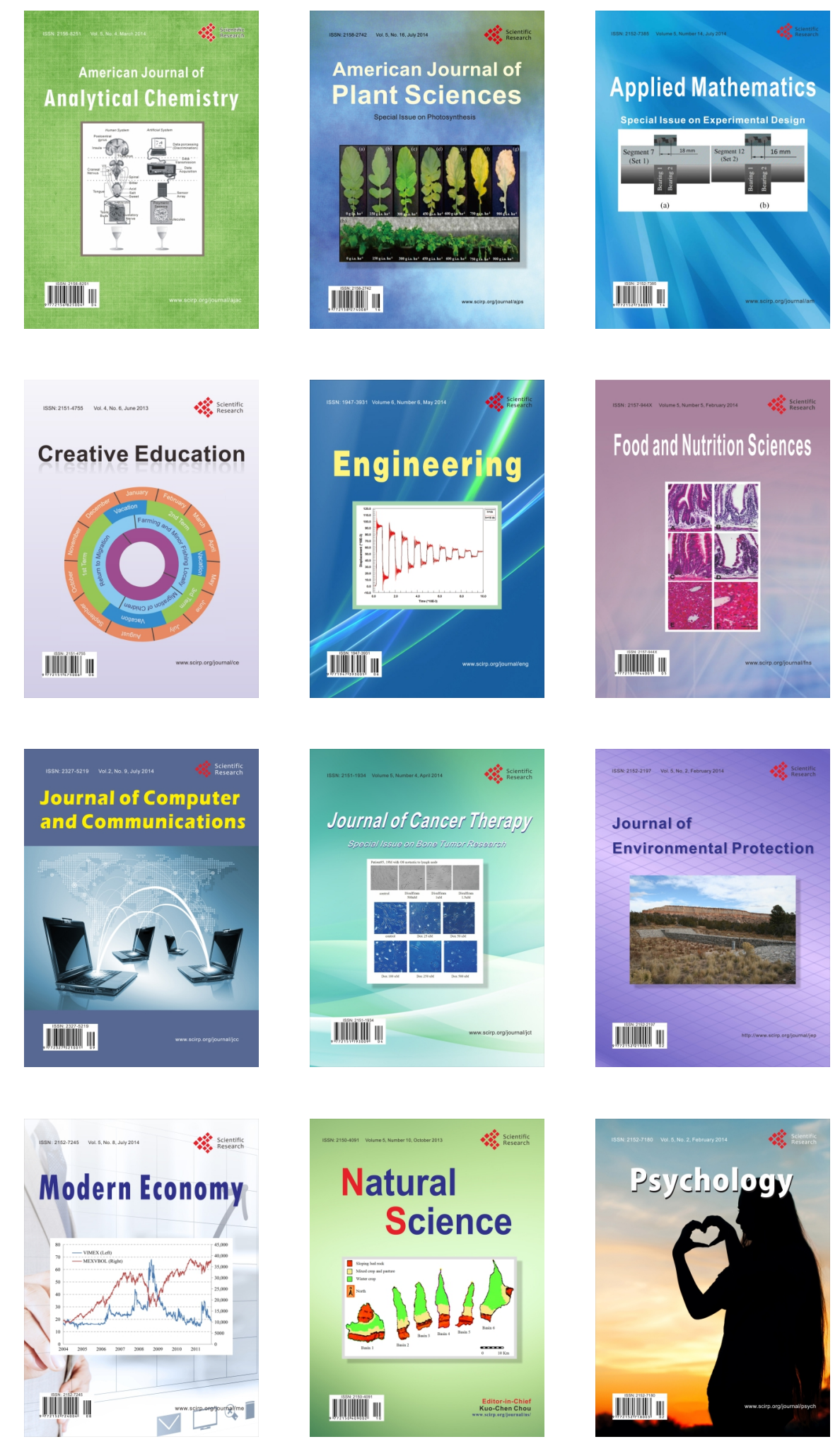